\title{
Occupational Diseases and IIInesses Affecting Rice Farmers in Afikpo North Local Government Area of Ebonyi State
}

\author{
Okereke D. I. ${ }^{1}$, Okereke S. N. $^{2}$ \\ ${ }^{1}$ Planning Unit, Federal College of Agriculture, Ishiagu, Ebonyi, Nigeria \\ ${ }^{2}$ Department of Public Administration, College of Agriculture, Ishiagu, Ebonyi, Nigeria
}

Email address:

davyokereke@yahoo.com (Okereke D. I.), samnokus@yahoo.com (Okereke S. N.)

\section{To cite this article:}

Okereke D. I., Okereke S. N. Occupational Diseases and Illnesses Affecting Rice Farmers in Afikpo North Local Government Area of Ebonyi State. Science Journal of Business and Management. Special Issue: Sustainable Entrepreneurial Developments in Agribusiness.

Vol. 3, No. 5-1, 2015, pp. 65-68. doi: 10.11648/j.sjbm.s.2015030501.24

\begin{abstract}
The research project was carried out to identify occupational diseases and illnesses affecting rice farmers in Afikpo North local government area of Ebonyi State, Nigeria. Structured questionnaires were used to obtain information from the area. A total of two hundred (200) questionnaires were designed and randomly distributed to selected rice farmers. The analytical tools used were frequency and percentage distribution tables. Results obtained showed that $51 \%$ of the respondents took ill at one time or the other, the diseases commonly suffered by the respondents are malaria $15.5 \%$, typhoid $12.5 \%$, cough $10 \%$, AIDS $9.5 \%$, hepatitis $8.5 \%$, and yellow fever $8 \%$, cholera and amoebiasis $7.5 \%$ respectively, ascariasis $7 \%$, ulcer and diarrhea 5\% respectively and hypertension 4\%. The most serious diseases were identified as guinea worm infection 30\%, followed by diarrhea and yellow fever $8 \%$ respectively, cholera 7\%, ascariasis $6 \%$, hepatitis $5.5 \%$ and amoebiasis $5 \%$. The respondents that usually visit hospitals constituted $24.5 \%$, herbal homes $19 \%$, diagnostic laboratories $18 \%$, self-medication $16 \%$, chemists $11.5 \%$ and spiritual homes $11 \%$. The inadequacy of medical services in the study area was also highlighted.
\end{abstract}

Keywords: Rice, Disease, Self-Medication, Diagnostics, Laboratory, Productivity

\section{Introduction}

Rice is one of the most important among the major crops grown in most part of the world and because of its versatility in supplying the food need of the people; it has formed the basic food of the world at large. Rice is regarded as the world's leading food which can be put to many uses in the industrial sector such as sachet food manufacturing like macrony, spaghetti, indomie noodles and even flour. It is also used for industrial/commercial production of beer and some other beverages in brewing industries. According to [1, 2], rice has been presumed to be the most popular cereal crop largely grown and consumed by almost half of the world's population.

\subsection{Disease Definition}

A disease is a particular abnormal, pathological condition that affects part or all of an organism. It is often construed as a medical condition associated with specific symptoms and signs. It may be caused by factors originally from an external source such as infectious disease, or it may be caused by internal dysfunctions such as autoimmune diseases. In human disease is often used more broadly to refer to any condition that causes pain, dysfunction, distress, social problem, or death to the person afflicted or similar problems, for those in contact with the person. In this broader sense, it sometimes includes, disorder, disability, syndromes, infections, isolated syndromes and atypical variations of structure and function, while on the other context and for other purposes these may be considered distinguishable categories. Diseases usually affect people not only physically, but also emotionally as contracting and living with a disease can alter one's perspective on life and one's personality. Death due to disease is called death by natural cause. Commonly, the term disease is used to refer specifically to infectious diseases which are clinically incident diseases that result from the presence of pathogenic microbial agents, including viruses, bacteria, fungi, protozoa, multicellular organisms and aberrant proteins known as prions. Disease can be classified as communicable and non-communicable. Death usually result due to diseases 
among people suffering from it. The great loss of lives, loss of useful man-hours of labour, the cost of treatment of patients and the negative impact of the disease make malaria a major social and economic burden [3,4]. The high prevalence of malaria in the country shows that malaria infection is endemic [5]. The high prevalence of malaria in tropical countries could be attributed to favourable climatic conditions prevailing in the country such as temperature, humidity and rainfall which regulate the biology of development of both the mosquito and the parasites [6] as well as the behavioural attitude of the inhabitants of the areas.

\subsection{Economic Importance of Diseases}

The impact of diseases on man, crops and livestock is quite alarming and responsible for most untimely deaths, huge economic losses and poor standard of living and so if nothing is done man will be at the mercy of diseases. It is on this note that present survey study was undertaken to identify the common and major diseases affecting rice farmers in Afikpo North local government area of Ebonyi State with a view to proffering and recommending solution of the current trend. It is believed that if the recommendations are taken will go a long way in improving the health standard of the people which ultimately will increase rice production.

The consequences of animal diseases in domesticated birds and livestock can be complex and generally go well beyond the immediate effects on affected producers. These diseases have numerous impacts including the productivity, losses for the livestock sector (e.g. production losses, cost of treatment, market disturbances); loss of income from activities using animal resources (in such sectors as agriculture, energy, transportation, tourism); loss of wellbeing of human beings (morbidity, mortality rates, food safety and quality); prevention or control cost (production cost, public expenditure on research among others). These economic and social effects can have both ripple (impact on the industry) and spillover (impact on other sectors) impact.

\subsection{Statement of the Problems}

Many people in the world do not have enough to eat, and this problem is likely to increase as the population increases. The important role of agriculture is to provide enough food for every one and generate employment to the people; therefore it is a business enterprise. Disease outbreak has been a source of worry at all levels of government, both locally and internationally. The effect of diseases on human race is so worrisome that something has to be done. Crop losses globally and annually are responsible for food scarcity in most developing countries. Disease have continued to pose serious health challenges of public importance both globally and nationally and has debilitating effect which significantly affects the quality of life, physically, mentally, socially, economically and academically.

In Nigeria economics of rice production as a veritable source of food and cash income to both rural and urban segments of the population is increasing and there is need for it to be sustained.
This can only be sustained if the health status of the farmers is guaranteed. There is evidence that eradication or reduction of disease incidence could lead to improved health and wellbeing of the people and poverty reduction. There are indications that people infected by diseases reduce their farm activities, business activities and income during infection periods and this have very serious economic consequences affecting the standards of living of the people.

Many people in Afikpo North have taken agriculture (rice production) as their business, but for a long time now, their achievements tend to be insignificant in the society because the production level of rice is less than the rising demand. One wonders then what are the problems associated with this situation are. Disease infection has been identified as a serious factor responsible for low production trends despite the fact that the environment is favourable for its cultivation.

The present study is necessitated by poor production output of rice, in spite of favourable environmental condition for its cultivation with a view to finding lasting solution to some of the challenges.

\subsection{Objectives of the Study}

Most critical among several recorded diseases affecting Africans and Nigerians, include: malaria, tuberculosis, typhoid fever, stroke, heart disease, ulcer, worm infection [guinea worm, schistosomiasis, onchocerciasis], hypertension, kidney disease, HIV/AIDS, cancer, gonorrhea, trichomoniasis, cholera, trypanosomiasis, hepatitis, and yellow fever; the list is endless. This study seeks to determine the impact of these diseases on rice farmers in Afikpo North local government area of Ebonyi State and how frequent rice farmers in the area take ill. The paper also seek to determine the adequacy of health services and the preparedness of the health services/clinic in facing such challenges.

\section{Materials and Methods}

\subsection{Description of the Study Area}

Afikpo is located at Latitude $5^{\circ}$ and $6^{\circ}$ north and longitude $7^{\circ}$ and $8^{\circ}$ east with an annual rainfall of $1200-1600 \mathrm{~mm}$, a mean temperature range of between $27^{\circ} \mathrm{C}-33^{\circ} \mathrm{C}$ It is a semi-urban town being a primary agricultural producer with extractive industry and education [7] as means of occupation. Within each community, compound farming is a common feature. Though, other farm sites with hamlet settlement and belonging to each community equally exist. The communities are homogenous in terms of ancestral decent and farming practices [8].

\subsection{Sampling Procedure}

Questionnaires were administered on the respondents and a time frame of two weeks was used for distribution and collection. A structured interview was conducted with selected farmers to validate the response filled in the questionnaires. In all, 200 questionnaires were administered and treated valid. 


\subsection{Data Analysis}

The collected data were subjected to descriptive statistics such as percentages and frequency distribution. This is necessary in order to determine the distribution of the respondents within the study area.

\section{Results and Discussion}

\subsection{Illness Distribution Characteristics Among Farmers}

Table 1 shows that the diseases mostly suffered by the respondents are malaria (15.08\%), typhoid $(12.56 \%)$, cough $(10.55 \%)$, AIDS $(9.05 \%)$, hepatitis $(8.54 \%)$, yellow fever $(8.04 \%)$, cholera and amoebiasis $(7.54 \%)$ respectively, diarrhea (5.03\%), ulcer (5.03\%) and hypertension (4\%).

Table 1. Distribution according to the type of illness.

\begin{tabular}{lll}
\hline Type of illness & Frequency & Percentage \\
\hline Malaria & 31 & 15.5 \\
Typhoid & 25 & 12.5 \\
Yellow fever & 16 & 5 \\
Cholera & 15 & 7.5 \\
Amoebiasis & 15 & 7.5 \\
Diarrhea & 10 & 5 \\
Ascariasis & 14 & 7 \\
Cough & 21 & 10 \\
Hepatitis & 17 & 8.5 \\
AIDS & 18 & 9.5 \\
Ulcer & 10 & 5.03 \\
Hypertension & 8 & 4 \\
Total & 200 & 100 \\
\hline
\end{tabular}

Field survey 2014

Outcome presented in Table 2 indicated that farmers usually get sick during the nursery stage $22.5 \%$, weeding $20 \%$, transplanting $17.5 \%$, threshing $15 \%$, land preparation and bird scaring $12.5 \%$ respectively. The result revealed that farmers take ill virtually during all activities associated with rice production.

Table 2. Distribution according to the period of rice production that rice farmers usually take ill.

\begin{tabular}{lll}
\hline Period rice farmers usually take & Frequency & Percentage \\
\hline Land preparation & 25 & 12.5 \\
Raising of nursery & 45 & 22.5 \\
Transplanting & 35 & 17.5 \\
Weeding & 40 & 20 \\
Bird scaring & 25 & 12.5 \\
Threshing & 30 & 15 \\
Total & 200 & 100 \\
\hline
\end{tabular}

Field survey 2014

From table 3, occupational diseases of rice farmers considered most critical are; guinea worm infection 30\% (60 respondents), malaria 17.5\% (23 respondents), typhoid 9\%
(18 respondents), yellow fever and diarrhea $8 \%$ respectively (16 respondents), cholera 7\% (14 respondents). The listed diseases are common because of farmer's close contact with water.

Table 3. Distribution according to the disease considered as the most serious.

\begin{tabular}{lll}
\hline Type of illness & Frequency & Percentage \\
\hline Malaria & 23 & 17.5 \\
Typhoid & 18 & 9 \\
Yellow fever & 16 & 8 \\
Cholera & 14 & 7 \\
Amoebiasis & 10 & 5 \\
Diarrhea & 16 & 8 \\
Ascariasis & 13 & 6 \\
Cough & 10 & 5 \\
Hepatitis & 11 & 5.5 \\
AIDS & 9 & 4.5 \\
Guinea worm infection & 60 & 30 \\
Total & 200 & 100 \\
\hline
\end{tabular}

Field survey 2014

\subsection{Diagnostic Characteristics of Infection Situation}

The diagnostic measures and treatment for affected farmers in Table four reveals that out of 200 respondents, $49(24.5 \%)$ visit the hospital for treatment, 35 [18\%], patronize the diagnostic laboratories, $22(11 \%)$ visit spiritual homes, 38 (19\%) sought medical treatment from herbal homes; $32(16 \%)$ engaged in self-medication; while $23(11.5 \%)$ obtained their treatments from chemists/medicine stores.

Table 4. Distribution according to where treatment is sought.

\begin{tabular}{lll}
\hline Where treatment is sought & Frequency & Percentage \\
\hline Hospital & 49 & 24.5 \\
Diagnostic laboratories & 36 & 18 \\
Spiritual homes & 22 & 11 \\
Herbal homes & 38 & 19 \\
Self-medication & 32 & 16 \\
Chemists/medicine stores & 23 & 11.5 \\
Total & 200 & 100 \\
\hline
\end{tabular}

Field survey 2014

\section{Conclusion}

\subsection{Conclusion}

Rice as one of the most important staple food grown in most parts of the world and because of its versatility in supplying the food need of the people; it has formed the basic food of the world at large, the need to increase its productivity becomes imperative. This can be achieved by improving the health standard of the farmers.

Results of the disease situation in Afikpo North local government area of Ebonyi State show that people took ill at one time or the other during the entire rice production processes; and this mostly affects the productivity level of farmers in the area. The diseases considered as the most serious a (guinea worm infection $30 \%$, malaria $17.5 \%$, typhoid $9 \%$, yellow fever, diarrhea $8 \%$ respectively, and cholera $7 \%$ ) fall among the diseases listed as occupational diseases of rice farmers because 
of their close contact with water.

\subsection{Recommendations}

At the end of the study the following recommendations are suggested for implementation which could reduce the incidence of disease among rice farmers as well as increase rice production, thus reducing food scarcity as well as poverty reduction.

1. Establishment of more hospitals and health centers: Establishment of hospitals and health centers is very critical in the treatment, prevention and control of diseases.

2. Engagement of more doctors: The role of trained medical personnel [doctors, nurses, laboratory scientists and other health workers] in the reduction of diseases cannot be over emphasized.

3. Enlightenment/health education: Enlightenment and health education should be vigorously pursued.

\section{References}

[1] Chad, B. (1992): Sustainable Agriculture. Possibility and Direction, Bangkok: National Science and Technology Development Agency. Crop Protection 32: 54.
[2] Abalu, K. (1981): The evolving story of rice evolution. Plant Science 174 (4): 394-408.

[3] Ukpai, O. M and E. I Ajoku. (2001): The prevalence of malaria in Okigwe and Owerri areas of Imo State. Niger. J. Parasitol; 22: 43-48.

[4] FAO. (2004): The state of food agriculture 2003-2004. Food and Agricultural Organization of the United Nations. pp: 180-208.

[5] World Health Organization. (2002): Roll back malaria. World Health Organization fact sheet No. 203, Geneva, Switzerland. Pp: 86-91. https:/apps.who.int/inf-fs/en/fact203.html.

[6] Imolehin, E. N and Wada, A. C. (2000): Meeting the rice need with improved technologies. International Rice Commission. Newsletters, 49. Pp 23-41.

[7] [Areola, O, Iruegbe, O. Ahmed, K; Adeleke, B and Leong G. C. (2001) Certificate Physical and Human Geography for senior secondary schs. Unui. Press Plc. 382 -384.

[8] Ebii, C. O. (2003) Farming systems and Brush fire culture: An Environmental issue in Ishiagu, Ebonyi State, Nigeria. $B i-$ weekly Seminar series FCAI PP.3. 